XLVIth Zakopane School of Physics, International Symposium Breaking Frontiers, Zakopane, Poland, May 16-21, 2011

\title{
FTIR Microspectroscopy in Studies of DNA Damage Induced by Proton Microbeam in Single PC-3 Cells
}

\author{
E. Lipiec, J. Kowalska, J. Lekki, A. Wiecheć and W.M. KwiateK* \\ The Henryk Niewodniczański Institute of Nuclear Physics, Polish Academy of Sciences \\ E. Radzikowskiego 152, 31-342 Kraków, Poland
}

\begin{abstract}
In recent years, the Fourier transformed infrared spectroscopy is often applied in studies of biological materials on cellular level. Undoubted advantage of this method is high sensitivity. In presented research the FTIR microspectroscopy was used to analyse the DNA damage in single PC-3 cells (prostate cancer cell line derived from bone metastases) irradiated by counted number of protons. Focused proton microbeam $2 \mathrm{MeV}$ from the Van de Graaff accelerator at the Institute of Nuclear Physics, Polish Academy of Sciences, was used as an irradiation source. Four groups of single cells were irradiated with 1000, 2000, 4000, and 8000 protons per cell, respectively. Following irradiation cells were fixed in $70 \%$ ethanol and then analyzed by IR microspectroscopy. Bond analysis of IR spectra served as a base for result analysis. This research has focused on the detection of changes in DNA backbone spectral range $\left(950-1240 \mathrm{~cm}^{-1}\right)$, which could be related to damages such as single and double strand breaks, DNA-DNA, and DNA-protein cross links. Switches and differences in intensity of DNA backbone bands $\left(980-1149 \mathrm{~cm}^{-1}, 1151-1350 \mathrm{~cm}^{-1}\right.$ - symmetric and asymmetric $\mathrm{PO}^{2-}$ stretching vibrations, as well as in $1110 \mathrm{~cm}^{-1}$ - symmetric stretching of $\mathrm{P}-\mathrm{O}-\mathrm{C}$ band) were observed. Experimental spectra of irradiated and control cells were compared with simulated spectra generated by HyperChem software. The multivariate statistical methods of principal component analysis and hierarchical cluster analysis (Ward's method) were also performed and are discussed.
\end{abstract}

PACS: 87.14.gk, 87.64.km, 78.30.Jw, 87.53.Bn

\section{Introduction}

Research of radiation dose-dependent biological effects (such as DNA damage: single and double strand breaks, cross-links and oxidative damages) enhances the understanding of the mechanisms leading to cell death. This may result in the increased effectiveness of radiotherapy, and thus increased chances of total cure of the patient and prevention of the metastases formation. Particularly microbeam facilities are an excellent tool for radiobiological studies due to their ability to deliver precise doses of radiation to selected individual cells in vitro. In the Department of Applied Spectroscopy at the Institute of Nuclear Physics, Polish Academy of Sciences a proton microprobe facility was built and it was adapted to living cells studies as a source targeted irradiation of single cells with the controlled number of protons [1-4].

To detect the DNA damage biochemical methods are generally used. However, they may influence the investigated sample, because of chemical substances used and complex preparation procedures. Most of them are not intended to single cells studies, such as electrophoresis, colorimetric tests: lactate dehydrogenase (LDH), mitochondrial succinate dehydrohenase (MTT). Therefore, the importance of application of complementary technique is evident. From possible methods, the Fourier transformed infrared (FTIR) spectroscopy is well known

* corresponding author; e-mail: wojciech.kwiatek@ifj.edu.pl for its uniqueness as a appriopriate tool in identifying vibrational structure of biological materials.

A growing number of literatures demonstrate the conformational aspects of proteins, nucleic acids and other biomolecules using FTIR. It is known that FTIR is a sensitive tool that can be applied to DNA damage study on chemical bond level thus it has become a potential analytical method in single cells studies [5-7].

In the presented study the human prostate adenocarcinoma derived from bone metastases - PC-3 line was used as a biological material. This cell line is often used as a model in prostate cancer study [8, 9]. The high degree of invasiveness of PC-3 line makes a very interesting research model.

\section{Materials and method}

\subsection{Cell culture and sample preparation}

PC-3 cells were cultured in RPMI 1640 medium, supplemented with $10 \%$ of FCS (fetal calf serum), $100 \mathrm{U} / \mathrm{ml}$ penicillin-streptomycin solution, $10 \mathrm{mM}$ HEPES, $1 \mathrm{mM}$ sodium pyruvate and $4.5 \mathrm{~g} / \mathrm{l}$ glucose (all compounds delivered by Sigma Aldrich Stenheim, Germany). Cultured cells were grown in $37^{\circ} \mathrm{C}$ and an atmosphere of $5 \% \mathrm{CO}_{2}$. To collect cells the $0.5 \%$ trypsin in phosphate buffered saline (PBS) was used.

For protons treatment, cells were seeded on specially prepared $35 \mathrm{~mm}$ diameter Petri dishes with $10 \mathrm{~mm}$ round holes in the central part of the bottom. The Petri dish bottom was covered with the $1.5 \mu \mathrm{m}$ thick Mylar foil 
(Goodfellow Cambridge Limited, Huntington, UK) using the glue (Master Bond EP 30 med, New York, USA). A population of about 10000 cells in $10 \mu \mathrm{l}$ medium were seeded in the central part of the Mylar foil 16-18 h before the experiments. Four hours after the seeding, when cells had adhered to the foil, $2 \mathrm{ml}$ of medium was added.

\subsection{Protons source and cells irradiation}

The $2 \mathrm{MeV}$ horizontal focused proton microbeam (the external beam of about $16 \mu \mathrm{m}$ in diameter at the irradiated spot) from the Van de Graaff accelerator was used as an irradiation source. During cell irradiation the beam current was about $0.16 \mathrm{fA}$, which corresponds to about 1000 protons per second with the $92 \%$ targeting accuracy. The silicon surface barrier particle detector (ORTEC B-019-300-150) was used for protons counting. Single cells were irradiated with four doses of protons in the range of 1000-8000 protons per cell and next incubated with medium in $37^{\circ} \mathrm{C}$ and the atmosphere of $5 \%$ $\mathrm{CO}_{2}$ for up to $24 \mathrm{~h}$. Not irradiated cells, but processed in the same way, were forming the experimental control group. After irradiation all cells were washed with PBS and fixed in $70 \%$ ethanol at $4{ }^{\circ} \mathrm{C}$.

\subsection{Analysis under IR microscopy}

FTIR spectra of 1-3 different cells (per spectrum) were collected. Spectra were taken in transmission mode with a resolution of $4 \mathrm{~cm}^{-1}$, in spectral range of 600 $4000 \mathrm{~cm}^{-1}$ for all groups of cells (irradiated and untreated by radiation). As the reference the Mylar foil was used. The extended spectral range was necessary to allow the use of the correction of the Mie scattering which improves the quality of the spectrum. The number of scans was set to 256 . In presented study the spectrometer Bruker IFS $66 \mathrm{v} / \mathrm{S}$ with a mercury cadmium telluride (MCT) detector and the microscope Bruker IRscope II were used. For all groups of cells (control and treated with protons) 20-30 spectra were taken.

As the first step, the baseline correction (second-degree polynomial) was done. Next the correction for the Mie scattering effect was applied. Optimally parameters were used during the corrections [10-12]:

- Number of iterations: 50 ;

- Mie theory option: resonant Mie scattering (RMieS);

- Lower range for scattering particle diameter: $2 \mu \mathrm{m}$;

- Upper range for scattering particle diameter: $12 \mu \mathrm{m}$;

- Lower range for average refractive index: 1.1;

- Upper range for average refractive index: 1.5 ;

- Reference spectrum: Matrigel (measured especially for this experiment)
The spectra of cells control group and irradiated ones (1000, 2000, 4000, and 8000) protons per cell were averaged respectively (Fig. 1). The spectra were analyzed by fitting the bands with Gaussian-Lorentzian curves (Fig. 2). Band fitting was performed in the spectral region of $800-1800 \mathrm{~cm}^{-1}$, because the presented experiment was focused on the detection of changes in DNA backbone spectral range $\left(950-1240 \mathrm{~cm}^{-1}\right)$. The number of peaks was chosen following the literature [13-15], and the intensity of some of them was set to 0 . The spectra were analyzed using Omnic software, and the band fitting was carried out by X-ray photoelectron spectroscopy (XPS) peak software.

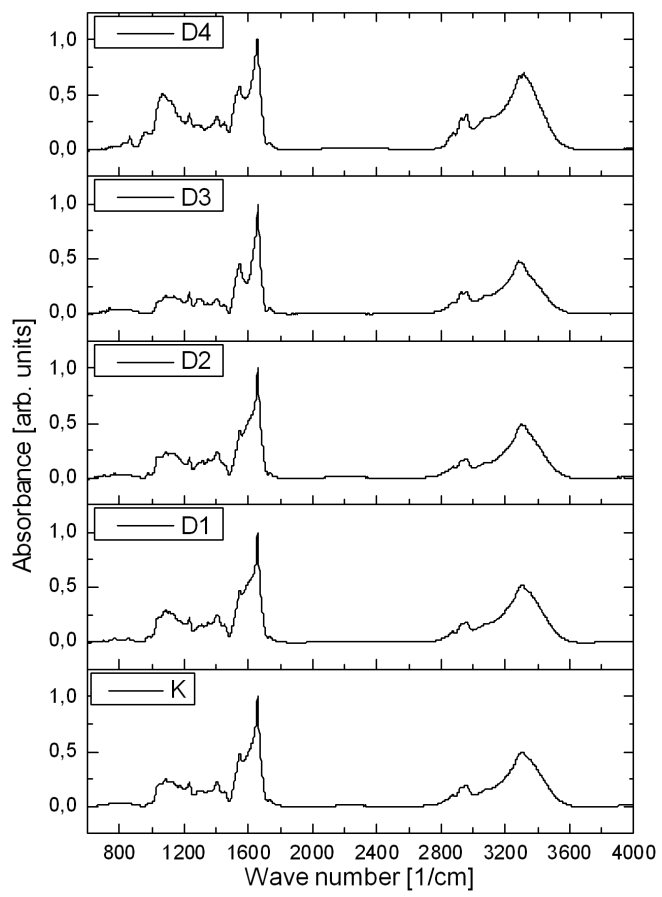

Fig. 1. The averaged spectra of control $(\mathrm{K})$ and cells irradiated with 1000 (D1), 2000 (D2), 4000 (D3), and 8000 (D4) protons per cell, respectively.

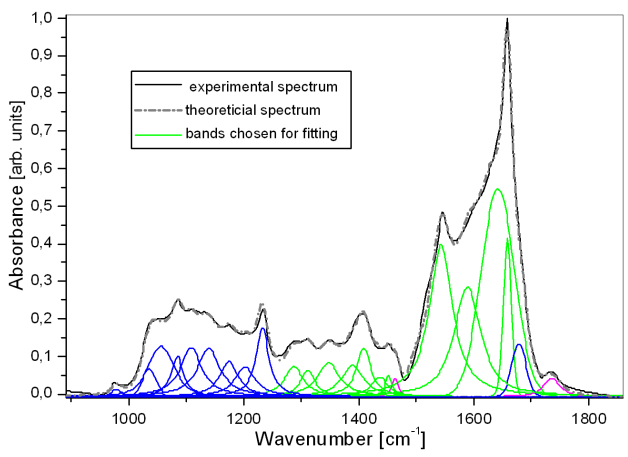

Fig. 2. Fitting analysis in the wave number region of 950-1800 $\mathrm{cm}^{-1}$ 


\section{Results}

\subsection{Hierarchical cluster analysis}

Spectral range $950-1240 \mathrm{~cm}^{-1}$ was analyzed using Ward's algorithm [16]. In presented method, an Euclidean distance produced dendrogram, which illustrates the degree of similarity between the averaged spectra of each cells (control and cells irradiated with 1000, 2000, 4000, 8000 protons per cell) (Fig. 3).

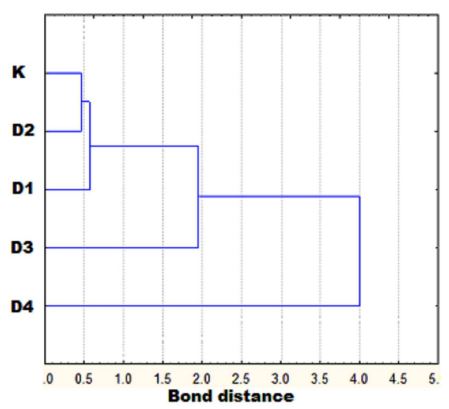

Fig. 3. Degree of similarity between the averaged spectra of each cells: control $(\mathrm{K})$ and cells irradiated with 1000 (D1), 2000 (D2), 4000 (D3), 8000 (D4) protons per cell. Not as expected, the cells irradiated by 2000 are most similar to the control group.

\subsection{Principal component analysis}

To detect the structure in the relationships between data, principal component analysis (PCA) of the spectral region $950-1240 \mathrm{~cm}^{-1}$ was performed using Statistica 8.0 software [17]. Five distinct clusters were evident for five groups of cells spectra (control and irradiated with 1000, 2000, 4000, 8000 protons per cell) (Fig. 4).

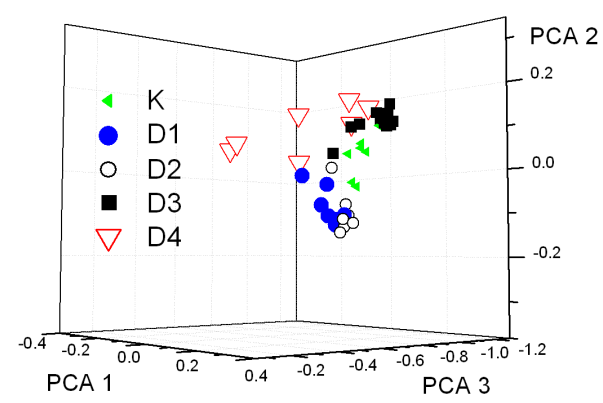

Fig. 4. Five distinct clusters for five groups of cells spectra (control (K) and cells irradiated with 1000 (D1), 2000 (D2), 4000 (D3), 8000 (D4) protons per cell).

\subsection{Fitting analysis}

The detection of changes in DNA backbone spectral range $\left(950-1240 \mathrm{~cm}^{-1}\right)$, can be related to damages such as single and double strand breaks. Also DNA-DNA and DNA-protein cross links were examined. Differences and switches in intensity of DNA backbone bands were observed in all irradiated cells.

All of the bands are presented in Table. The experimental spectrum of control cells and the averaged theoretical model are presented in Fig. 2. Bands at 980$1149 \mathrm{~cm}^{-1}, 1151-1350 \mathrm{~cm}^{-1}$ are attributed to symmetric and asymmetric $\mathrm{PO}^{2-}$ stretching vibrations [2], while at $1110 \mathrm{~cm}^{-1}$ to symmetric stretching of $\mathrm{P}-\mathrm{O}-\mathrm{C}$ band and at $970 \mathrm{~cm}^{-1}$ — ribose-phosphate skeletal motions $[3,4]$.

DNA infrared bands of cells in spectral range

TABLE $800-1800 \mathrm{~cm}^{-1}[12,13]$.

\begin{tabular}{|c|c|}
\hline $\begin{array}{l}\text { Wave number } \\
{\left[\mathrm{cm}^{-1}\right]}\end{array}$ & Assignment [13-15] \\
\hline \multicolumn{2}{|r|}{ Lipids } \\
\hline 1462 & $\mathrm{CH}_{3}$ asymmetric bending \\
\hline 1732 & $\mathrm{C}=\mathrm{O}$ stretching \\
\hline \multicolumn{2}{|r|}{ Proteins } \\
\hline 1294 & $\begin{array}{l}30 \% \mathrm{C}-\mathrm{N} \text { stretching; } 30 \% \mathrm{~N}-\mathrm{H} \text { bending; } \\
10 \% \mathrm{C}=\mathrm{O} \text { stretching; } 10 \% \mathrm{O}=\mathrm{C}-\mathrm{N} \text { bending; } \\
20 \% \text { other (amide } \mathrm{III} \text { ) }\end{array}$ \\
\hline 1313,1348 & $\mathrm{O}-\mathrm{H}$ bending (serie) \\
\hline 1380 & $\mathrm{CH}_{3}$ symmetric bending (leucine) \\
\hline 1406 & $\begin{array}{l}\text { the carboxylate anion and the a-CHa scissors } \\
\text { deformation of the carboxylic acid }\end{array}$ \\
\hline 1426 & $\mathrm{CO}_{2}$ symmetric stretching (glutamic acid) \\
\hline 1451 & $\begin{array}{l}\mathrm{CH}_{3} \text { asymmetric bending in valine, } \\
\text { benzene ring vibrations (tyrosine) }\end{array}$ \\
\hline 1546 & $\begin{array}{l}60 \% \mathrm{~N}-\mathrm{H} \text { bending; } \\
40 \% \mathrm{C}-\mathrm{N} \text { stretching (amide II) }\end{array}$ \\
\hline $1585-1642$ & $\begin{array}{l}80 \% \mathrm{C}=\mathrm{O} \text { stretching; } 10 \% \mathrm{C}-\mathrm{N} \text { stretching; } \\
10 \% \mathrm{~N}-\mathrm{H} \text { bending }\end{array}$ \\
\hline 1650 & $\mathrm{C}=\mathrm{O}$ stretching (aspargine) \\
\hline \multicolumn{2}{|r|}{ Nucleic acids } \\
\hline 970 & ribose-phosphate skeletal motions (DNA) \\
\hline 1038 & ribose $\mathrm{C}-\mathrm{O}$ stretching (RNA) \\
\hline 1055 & ribose $\mathrm{C}-\mathrm{O}$ stretching \\
\hline 1086 & $\mathrm{PO}_{2}$ symmetric stretching (DNA) \\
\hline 1105 & $\mathrm{P}-\mathrm{O}-\mathrm{C}$ symmetric stretching (DNA) \\
\hline 1144 & ribose $\mathrm{C}-\mathrm{O}$ stretching (RNA) \\
\hline 1175 & sugar-phosphate backbone vibrations \\
\hline 1212 & $\mathrm{C}-\mathrm{H}$ ring bending (RNA) \\
\hline 1230 & $\mathrm{O}-\mathrm{P}-\mathrm{O}$ asymmetric stretching (DNA) \\
\hline 1680 & $\mathrm{C}=\mathrm{O}$ stretching $(\mathrm{RNA})$ \\
\hline
\end{tabular}

All changes in spectra of cells irradiated by 1000 and 2000 protons per cell were insignificant, but they were substantial at 4000 and the biggest by 8000 (Fig. 5, Fig. 6). Figures 5 and 6 present the area under DNA backbone bands for all groups of cells (control and treated with different dosages of protons). Figure 5 shows the sum of changes of an intensity of all four peaks together. Figure 6 presents the changes of individual peak separately. The standard deviations were presented at both figures (Fig. 5, Fig. 6).

An area of $\mathrm{O}-\mathrm{P}-\mathrm{O}$ symmetric stretching band increased with the number of protons and an area of $\mathrm{P}-\mathrm{O}-\mathrm{C}$ symmetric stretching band decreased with the 


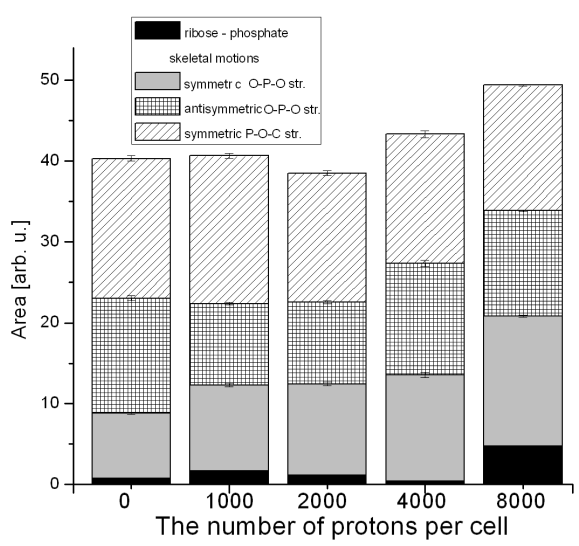

Fig. 5. The total area of DNA backbone bonds in spectra of irradiated and control cells.

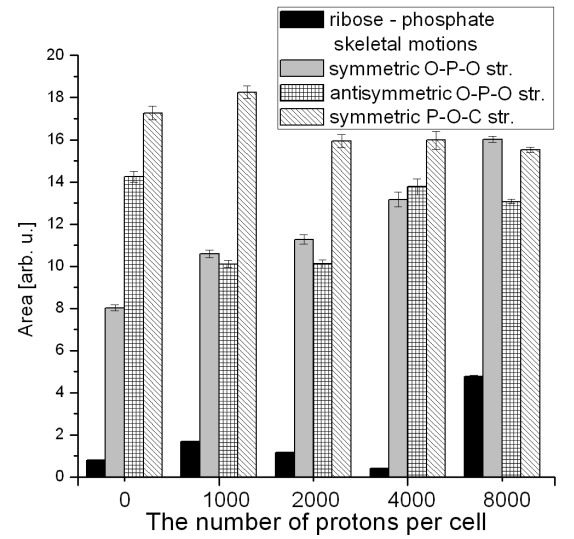

Fig. 6. The individual area of DNA backbone bonds in spectra of irradiated and control cells.

number of protons. It could mean that the probability of DNA strand breaks by destroying $\mathrm{C}-\mathrm{O}$ bond is higher than $\mathrm{O}-\mathrm{P}$ one. An increase of the area under the band corresponding to motion bond in phosphate DNA backbones may be due to destroyed chromosomal structure. Fragmentation of chromosomes could cause increase the number of molecule freedom degrees. The emerging of a new peak at about $830 \mathrm{~cm}^{-1}$ in spectra of cells irradiated with 8000 protons per cell was observed (Fig. 1). HyperChem simulations show that the peak could be correlated with single strand break (SSB). PCA analysis shows some clustering between all groups of spectra (control and irradiated with four different doses of protons).

\section{Conclusions}

Aim of this study was to find if infrared microscopy can be used in radiation DNA damage detection. Statistical analysis shows that there are differences between spectra of irradiated by different dosages of protons and control cells. Fitting analysis allows to follow small changes in spectra. Presented results prove that infrared microspectroscopy could be useful tool in DNA damage study in single cells.

\section{References}

[1] W. Polak, J. Lekki, O. Veselov, Z. Stachura, J. Styczeń, Acta Phys. Pol. A 109, 417 (2006).

[2] W. Polak, O. Veselov, J. Lekki, Z. Stachura, M. Zazula, R. Ugenskiene, M. Polak, Z. Styczeń, Nucl. Instrum. Methods Phys. Res. B 249, 743 (2006).

[3] R. Ugenskiene, J. Lekki, W. Polak, M. Prise, M. Folkard, O. Veselov, Z. Stachura, W M. Kwiatek, M. Zazula, J. Stachura, Nucl. Instrum. Methods Phys. Res. B 260, 159 (2007).

[4] O. Veselov, W. Polak, J. Lekki, Z. Stachura, K. Lebed, J. Styczeń, R. Ugenskiene, Rev. Sci. Instrum. 77, 055 (2006).

[5] E. Krupnik, M. Jackson, R.P. Bird, I.C. Smith, H. Mantsch, Proc. SPIE 3257, 307 (1998).

[6] G.I. Dovbeshko, N.Y. Gridina, E.B. Kruglova, O.P. Pashchu, Talanta 53, 233 (2000).

[7] J.K. Pijanka, A. Kohler, Y. Yang, P. Dumas, S. Chio-Srichan, M. Manfait, G.D. Sockalingum, J. Sulé-Suso, Analyst 134, 1176 (2009).

[8] M.E Kaighan, S. Narayan, Y. Ohunki, J.F. Lechner, L.W. Jones, Investig. Urol. 17, 16 (1979).

[9] F. Alimiraha, J. Chena, Z. Basrawalab, H. Xina, D. Choubeya, FEBS Lett. 580, 2294 (2006).

[10] P. Bassan, A. Kohler, H. Martens, J. Lee, H.J. Byrne, P. Dumas, E. Gazi, M. Brown, N. Clarke, P. Gardner, Analyst 135, 268 (2010).

[11] P. Bassan, H.J. Byrne, F. Bonnier, J. Lee, P. Dumas, P. Gardner, Analyst 134, 1586 (2009).

[12] P. Bassan, H.J. Byrne, J. Lee, F. Bonnier, C. Clarke, P. Dumas, E. Gazi, M.D. Brown, N.W. Clarke, P. Gardner, Analyst 134, 1171 (2009).

[13] B. Stuart, Infrared Spectroscopy. Fundamentals Applications, Wiley, New York 2004.

[14] G. Socrates, Infrared Characteristic Group Frequencies, Wiley, New York 2004.

[15] M. Banyay, M. Sarkar, A. Gräslund, Biophys. Chem. 104, 477 (2003).

[16] http://www.statsoft.com/textbook/ cluster-analysis/.

[17] http://www.statsoft.com/textbook/ principal-components-factor-analysis/ . 